Jolanta Kruk

https://doi.org/10.26881/pwe.2018.42.09

ORCID: 0000-0001-9599-0446

Wyższa Szkoła Bankowa w Gdańsku

jolanta.i.kruk@gmail.com

\title{
Pracownia wczesnej edukacji jako środowisko uczące. Rekonstrukcja teoretyczna i uwagi praktyczne
}

\section{Summary \\ Early education workshop as learning environment. Theoretical reconstruction and practical recommendations}

The paper pertains to the reconstruction of theoretical assumptions related to the education process of early education teachers with the use of learning environment. It is a proposition of reshaping the current preparatory schedule for teachers working with children from its traditional form into a formula based on laboratory work. Among various topics the article discusses theoretical grounds for the early education workshop derived from the concept of the learning environment. It also attempts to define the discussed terms in the cultural context. The article closes with a section devoted to practical recommendations worth taking into account when establishing the workshop.

Keywords: early education workshop, teacher education, laboratory, learning environment, teaching tools and aids

Słowa kluczowe: pracownia wczesnej edukacji, kształcenie nauczycieli, laboratorium, środowisko uczenia, narzędzia i pomoce dydaktyczne

\section{Wprowadzenie}

Proces przygotowywania zawodowego nauczycieli do ich przyszłej roli jest niezwykle złożony i wieloaspektowy. Jednak można założyć, że w dużej mierze stanowi on odzwierciedlenie dynamiki zmiany kulturowej, której wszyscy podlegamy. Współczesne wyzwania stojące przed pedagogami i ich pracą dydaktyczną związane są z przyspieszeniem cywilizacyjnym i skłaniają do przyjęcia założenia, iż dawne rozumienie środowiska uczenia kojarzone z klasą wyposażoną w ławki i tablice, rzutniki, czy inne pomoce dydaktyczne, obecnie w żaden sposób nie oddaje prawdziwych potrzeb związanych z otoczeniem, w którym obecnie się poruszamy, uczymy i badamy świat. W poszczególnych partiach tekstu opisuję uwarunkowania kształcenia nauczycieli w kontekście wymogów formalnych, a w szczególności podstawy programowej dla wychowania przedszkolnego i edukacji wczesnoszkolnej. Zastanawiam się nad możliwościami realizacyjnymi projektu pracowni usytuowanej w instytucji kształcącej pedagogów na poziomie wczesnej edu- 
kacji w powiązaniu z kształceniem dualnym, a także nad warunkami formalnymi i organizacyjnymi związanymi z przygotowaniem i wyposażeniem pracowni w kontekście istniejących wymogów formalno-prawnych. Prezentowany pomysł pracowni stanowi kontynuację prac nad środowiskiem uczącym, którego realnym efektem była organizacja Laboratorium Wczesnej Edukacji (LWE), działającego na rzecz nauczycielek/li tego etapu kształcenia w jednej z uczelni w północno-wschodniej Polsce. Projekt skierowany był do nauczycielek/li, a także studentek/ów pedagogiki (zintegrowana edukacja wczesnoszkolna). Laboratorium było jednocześnie miejscem zajęć, dyskusji, krytyki i analiz metodycznych oraz bazą pomocy dydaktycznych. W trakcie pracy nad formułą LWE uwidoczniła się konieczność gruntownej reorganizacji formalnej i merytorycznej procesu kształcenia przyszłych pedagogów. Przede wszystkim - poza potrzebą reorganizacji środowiska uczenia się i wynikających z nich wzorów metodycznych - niezbędne okazuje się ścisłe powiązanie procesu kształcenia w uczelni z placówkami szkolnymi i przedszkolnymi w ramach nieokazyjnej, pogłębionej współpracy. Pewne nadzieje pokładać można w koncepcji kształcenia dualnego, która może stać się pierwszym etapem profesjonalizacji nauczycielskiej. Na tych spostrzeżeniach powstał projekt powołania pracowni wczesnej edukacji, którego szkic przedstawiam w niniejszym tekście.

\section{Zmiana kulturowa a środowisko uczące}

W założeniach projektu kategorię środowisko uczące wywodzę ze sfery kultury, co wiąże się ze zróżnicowanymi kontekstami zdobywania wiedzy. Przyjmuję też, iż interakcje zachodzące pomiędzy ludźmi odbywają się w oparciu o narzędzia komunikacji, które decydują o sposobie rozumienia sfery symbolicznej, w której żyjemy. Dzięki temu możliwe staje się odczytywanie, interpretowanie i tworzenie nowych znaczeń dla zjawisk, procesów i artefaktów, z którymi stykają uczący się w swym otoczeniu. Przyjmuję także, iż to, co do niedawna było obejmowane ogólną kategorią „przestrzeń szkolna”, w jej dawnym rozumieniu (sprzed epoki cyfrowo-kulturowej zmiany), oddziela ją od pozaszkolnego kontekstu, tworząc zafałszowany obraz współczesnego środowiska uczenia się. Infrastruktura, z której korzystają uczniowie i pedagodzy odgrywa kluczową rolę, może być awangardą kształtującą nowe modele dydaktyczne i metodyczne (Bruner 2006). W niniejszym tekście środowisko uczenia się jest kategorią niemetodyczną i interdyscyplinarną; jej źródeł należy poszukiwać w filozofii kultury. Od dawna ludzie korzystają z otaczającej przestrzeni w specyficzny sposób różniący nas od świata zwierząt. Gatunkowa aktywność człowieka w naturalnym środowisku nie polega tylko na zapewnianiu sobie bezpieczeństwa, lecz także na zaspokajaniu zróżnicowanych potrzeb, takich jak: ciekawość, eksplorowanie otoczenia, pomysłowość, korzystanie z nowych informacji (Hall 1978: 10). Włączenie szerokiego rozumienia środowiska uczącego w obręb zainteresowania dydaktyków może przynieść kilka znaczących korzyści teoretycznych i praktycznych, do których można zaliczyć:

- określenie poprzez środowisko uczące wspólnego obszaru aktywności dla form kształcenia formalnego i nieformalnego; 
- wypracowanie środowiskowych ścieżek uczących, będących alternatywą dla klasycznych, wąsko-metodycznych wzorców stosowanych w obrębie instytucji kształcących;

- w nawiązaniu do tradycji kształcenia interdyscyplinarnego bardziej efektywne stanie się integrowanie wiedzy z różnych dyscyplin przy pomocy interdyscyplinarnej kategorii jaką jest środowisko uczace.

Do znaczących elementów środowiska uczacego należą wszelkie artefakty, które ułatwiają eksplorowanie, eksperymentowanie, przy wykorzystaniu pozaszkolnej przestrzeni kształcącej, takiej jak np.: biblioteki, teatry, muzea, place zabaw, interesujące obiekty architektoniczne wraz z infrastrukturą i wszelkie inne elementy środowiska człowieka, mające dla niego wartość poznawczą (Kruk 2014: 300 i nast.).

Jednak najbardziej interesujące i inspirujące edukacyjnie środowisko nie spełni zakładanych celów, jeśli nie będzie połączone ze sprzyjającą infrastrukturą otaczającą instytucje oświatowe zarówno na płaszczyźnie formalnej (przepisy i akty prawne) jak i wykonawczej (procedury szkolne, przyjęte wzorce metodyczne). Poniżej poruszam najbardziej zapalne wątki związane $\mathrm{z}$ trudnościami w uwolnieniu kreatywności nauczycieli i poczuciem sprawstwa pedagogicznego w ich miejscu pracy.

\section{Konteksty profesjonalizacji nauczycieli a ich poczucie sprawstwa}

Proces kształcenia i późniejszego usytuowania zawodowego nauczycieli w ramach szkolnictwa elementarnego jest silnie uwarunkowany społecznie, a ściślej - funkcjonuje w ramach formalnych wymogów ujętych w ustawy, rozporządzenia i przepisy wykonawcze, tworzące gęstą sieć oplatającą pedagogów i sterującą ich aktywnością. Często działania dydaktyczne podejmowane przez nauczycieli lokują się w z góry ustalonych ramach i wszelkie ich przekroczenie staje się mało prawdopodobne. Dzieje się tak dlatego, iż postępujący proces petryfikacji reguł życia społeczno-politycznego ostatnich lat nie pomija też sfery edukacji, zarówno w odniesieniu do kształcenia nauczycieli dla potrzeb szkolnictwa podstawowego, jak i zawodowego oraz na szczeblu szkolnictwa wyższego, związanego z dydaktyką akademicką. Problem ten, podejmowany od lat w pedagogice znalazł swój wyraz w licznych publikacjach badaczy (por. Kwiatkowska 2005; Klus-Stańska, Nowicka 2009; Rutkowiak, Potulicka 2010; Bauman 2011; Śliwerski 2013, 2015; Gołębniak, Zamorska 2014). Argumenty podnoszone przez pedagogów są niezmienne; jednak ich postulaty kierowane w stosunku do władz oświatowych o uwolnienie samodzielności i kreatywności dydaktycznej nauczycieli pozostają bez echa. Badacze piszą o ,gorsecie” krępującym wszelkie niezależne poczynania poszukujących nauczycieli, który jest dla nich utrudnieniem w samorealizacji zawodowej i przez swą szczegółowość utrudnia samodzielność dydaktyczną (Śliwerski 2015: 70). Inny ważny wątek dotyczy trudności w odnalezieniu się nauczycieli w permanentnie „reformowanej” rzeczywistości edukacyjnej, poddanej równocześnie naporowi kulturowych wzorców neoliberalizmu ekonomicznego: „Nauczyciele zdają się widzieć reformę jako społecznie wyabstrahowa- 
ny zestaw reguł ukierunkowujących poszczególne wewnątrzszkolne rozwiązania, (...). Rozwiązań tych nie osadza się jednak w szerszym horyzoncie społeczno-kulturowym" (Rutkowiak 2010: 267).

Kolejnym znaczącym kontekstem funkcjonowania nauczycielskiego są utrudnienia systemowe, w szczególności związane pogłębianiem ich profesjonalizmu. Badacze zwracają uwagę, iż nauczyciele w trakcie swego rozwoju zawodowego powinni mieć szansę na refleksyjną zmianę i możliwość porzucania nieprzydatnych, wyuczonych wzorców. Potrzebują zatem wielostronnego wsparcia odnoszącego się do ich aktywności praktyczno-badawczej, umiejętności definiowania i niwelowania pojawiających się trudności w pracy dydaktycznej, osadzania swych działań w szerszym kontekście społecznym w trakcie współpracy z innymi podmiotami (Gołębniak, Zamorska 2014: 119-125).

W odniesieniu do etapu kształcenia elementarnego najbardziej niepokojąca jest rozbieżność pomiędzy deklaratywnymi celami i zadaniami dydaktycznymi, sformułowanymi w podstawie programowej dla klas początkowych a realną ich wykładnią i możliwościami realizacyjnymi. W dokumencie opublikowanym na stronach MEN zamieszczono poniżej wyróżnione przeze mnie hasła w obowiązującej podstawie programowej, z których powinien korzystać w trakcie swej pracy dydaktycznej nauczyciel: „Wspieranie samodzielnej dziecięcej eksploracji świata, (...). Tworzenie warunków pozwalających na bezpieczną, samodzielną eksplorację otaczającej dziecko przyrody, stymulujących rozwój wrażliwości i umożliwiających poznanie wartości oraz norm odnoszących się do środowiska przyrodniczego, adekwatnych do etapu rozwoju Tworzenie warunków umożliwiających bezpieczną, samodzielną eksplorację elementów techniki w otoczeniu, konstruowania, majsterkowania, planowania i podejmowania intencjonalnego dzialania, prezentowania wytworów swojej pracy). Aranżacja przestrzeni wplywa na aktywność wychowanków, dlatego proponuje się takie jej zagospodarowanie, które pozwoli dzieciom na podejmowanie różnorodnych form dzialania. Elementem przestrzeni są także zabawki i pomoce dydaktyczne wykorzystywane w motywowaniu dzieci do podejmowania samodzielnego dzialania, odkrywania zjawisk oraz zachodzących procesów, utrwalania zdobytej wiedzy i umiejętności, inspirowania do prowadzenia wlasnych eksperymentów." (wszystkie pokreślenia autorskie).

Każde z zaznaczonych haseł stanowić może znakomitą inspirację dla twórczości pedagogicznej na niwie wczesnej edukacji. Zarówno samodzielna dziecięca eksploracja otaczającej przyrody, poznawanie elementów techniki w otoczeniu, konstruowanie, majsterkowanie, planowanie, podejmowanie intencjonalnego działania stymulującego rozwój wrażliwości - wszystko to jest dobrym punktem wyjścia dla uwolnienia nauczycielskiej samodzielności dydaktycznej. Podobnie należy się zgodzić, że aranżacja przestrzeni wpływa na aktywność wychowanków i podejmowanie przez nich różnorodnych form działania. Nauczyciel może też znaleźć pole do budowania swej wiedzy i poczucia kompetencji poprzez organizację przestrzeni pracy dydaktycznej, uzupełniając zbiory środków i pomocy dydaktycznych w celu motywowania dzieci do podejmowania samodzielnego działania, odkrywania zjawisk oraz zachodzących w otoczeniu procesów, utrwalania 
zdobytej wiedzy i umiejętności, inspirowania do prowadzenia własnych eksperymentów. Jest jednak jeden warunek - te sformułowania muszą zostać potraktowane jako wiążące przez wszystkie zaangażowane strony procesu dydaktycznego. A zatem - konieczne jest nie tylko zapewnienie odpowiednich środków finansowych oraz infrastruktury materialnej, lecz także znaczące przebudowanie metodyki pracy nauczycielskiej na tym etapie kształcenia, jak również przygotowanie samych pedagogów do odmiennego stylu pracy w zmiennym i dynamicznym środowisku, podlegającym wpływom współczesnej cywilizacji. Formułując dla potrzeb wczesnej edukacji koncepcję uczenia środowiskowego, przyjmuję jednocześnie założenie o konieczności takiej organizacji procesu kształcenia nauczycieli, który stałby się pierwszym etapem rekonstrukcji zarówno teorii jak i praktyki dydaktycznej w obszarze wczesnej edukacji. Jeżeli podstawa programowa ma być faktycznie stosowanym dokumentem w pracy nauczycielskiej, należy dokonać gruntownej reorientacji w przygotowaniu do zawodu pedagogów dla potrzeb kształcenia elementarnego. W przeciwnym razie postulowane w dokumentach MEN-u dobre praktyki będą kolejną papierową zmianą przyczyniającą się do tworzenia opisów nieadekwatnych do rzeczywistych realiów. Wynika to z faktu, że pomimo krytycznej świadomości nauczycieli, akademików, rodziców i innych zaangażowanych stron, proces reprodukcji wzorców metodycznych we wczesnej edukacji jest trudny do przerwania ze względu na transmisyjny charakter kształcenia nauczycieli (Bauman 2015: 132 i nast.; Gomuła, Dyrda 2006: 249), a istniejące modele progresywnego kształcenia pedagogów nadal nie są dostatecznie upowszechniane.

Powodem zwrócenia uwagi na obowiązujące dokumenty oświatowe są wymogi metodyczne, jakie pojawiają się z wraz z rekomendacjami dotyczącymi realizacji podstawy programowej. Wymogi te bywają niekiedy sprzeczne $\mathrm{z}$ hasłami programowymi zawartymi w podstawie programowej jak w przykładowym sformułowaniu: „(...) Uczeń: wykonuje przedmioty użytkowe, w tym dekoracyjne i modele techniczne: a) z zastosowaniem połączeń nierozłącznych: sklejanie klejem, wiązanie, szycie lub zszywanie zszywkami, sklejanie taśmą itp., b) używając połączeń rozłącznych: spinanie spinaczami biurowymi, wiązanie sznurkiem lub wstążką ozdobną."

Umiejętności te - być może znaczące w wielu sytuacjach - nie są chyba jednak kluczowe dla przygotowania ucznia z zakresu informacji technicznej, wydają się ponadto nadmiernie drobiazgowe i utrudniające samodzielność dydaktyczną, zwłaszcza, w kontekście sformułowanego w tym dokumencie postulatu o innowacyjnej i twórczej postawie nauczyciela.

\section{Pracownia wczesnej edukacji - założenia wstępne}

Niezależnie od opisanych trudności, wydaje się, że w podstawie programowej istnieje ukryty potencjał dla wolności przyszłej/go nauczycielki/a edukacji wczesnoszkolnej. Jest on zawarty w opisach postulowanego środowiska uczenia się. Jeżeli takie środowisko - zgodnie z zaleceniami MEN - zostanie siłami grona pedagogicznego utworzone, wówczas jego 
autoteliczna wartość $\mathrm{w}$ danej placówce zacznie przynosić bardzo szybko efekty w postaci pola interakcji pomiędzy wszystkimi zaangażowanymi uczestnikami. Można przyjąć też, że jest szansa na uruchomienie procesu przekształcania postępowania dydaktycznego zgodnego z metodyką odwzorowującą (ekspercką) w swobodną komunikację, opartą na praktykach kulturowych (Kruk 2015: 10 i nast.). Zasady, metody, formy i dobór środków realizacyjnych dla działań edukacyjnych w kontekście kulturowym określam mianem metodyki kulturowej, zaś procesy uczenia się-uczeniem środowiskowym. Wynika to z założenia o zakorzenieniu każdej poznawczej aktywności człowieka w specyfice kulturowej danego miejsca i czasu, nadającej jej odrębny, niepowtarzalny rys. Kultura, która tworzy ramy komunikacji międzyludzkiej, stanowi wyposażenie danej społeczności, zaś dzięki procesowi uczenia możliwe staje się tworzenie unikalnych wzorów i schematów kształcenia. Miejscem, w którym takie procesy mogą być badane, opisywane i testowane w warunkach laboratoryjnych jest pracownia przygotowująca nauczycielki/li do zawodu. Jej działanie różni się od typowego schematu tym, że niejako wymusza odmienny typ aktywności uczących się. Polega on głównie na badaniu, prowokowaniu czynności eksploracyjnych oraz bieżącym ewaluowaniu poszczególnych zadań dydaktycznych, przy wykorzystaniu profesjonalnego wsparcia. Niezależnie od wagi ustaleń teoretycznych, nauczycielskim polem aktywności jest warunkująca ją realność materialna. Proponując odrzucenie perspektywy teoriocentrycznej, zakładam jednocześnie, że wiedza przyszłych nauczycielek/li powstająca w trakcie działania w uczacym środowisku stanowi kontekst dla ich nowych praktyk poznawczych i refleksji. Koncepcja uczenia środowiskowego oraz pracowni wczesnej edukacji została osadzona w paradygmacie krytycznej filozofii technicznej, które zostały obszerniej omówione w innych opracowaniach, w których odwołuję się do teorii aktora-sieci (ANT) (Afeltowicz 2011; Latour 2010; Abriszewski 2007).

Idea kształcenia nauczycieli w otoczeniu szkolnym, w przygotowanych warunkach nie jest nowa; już pedagodzy czasów Nowego Wychowania opisywali konieczne warunki i założenia pracy przyszłych nauczycieli. Zarówno John Dewey, Maria Montessori, Helen Parkhurst, Owidiusz Decroly i wielu innych twórców nie tylko opisywali założenia określonych szkół alternatywnych, lecz także tworzyli zaplecze umożliwiające realizowanie idei edukacyjnych przez odpowiednio przygotowanych nauczycieli. Także współczesne projekty alternatywnych rozwiązań metodycznych znajdują ramy realizacyjne we współpracujących placówkach. Obecne systemy kształcenia nauczycieli dysponują zasobami kadry dydaktycznej i administracyjnej, salami wykładowymi, bibliotekami i pozostałą, bogatą infrastrukturą wspierającą kształcenie. Jednak nawet najbardziej nowoczesne placówki kształcące nauczycieli wydają się pozbawione tego, co jest sercem aktywności przyszłych pedagogów: kontekstu szkolnego, wyrażającego się w stałym kontakcie z uczniami, atmosferą klasy szkolnej lub sali przedszkolnej, codziennych trudności i znaczących dla pedagogów zdarzeń. Dlatego jednym z założeń projektu pracowni kształcenia nauczycieli jest jej środowiskowy charakter. Uzyskanie pożądanych warunków obecnie stało się realne po wprowadzeniu na uczelniach możliwości kształcenia dualnego, polegające na naprzemiennym studiowaniu i pracy w placówkach, mających odpowiednie 
uprawnienia i dysponujące kadrą tutorską. Granica pomiędzy placówką a uczelnią staje się bardziej elastyczna, gdyż w takim modelu możliwe jest prowadzenie zajęć na terenie uczelni przez nauczycieli-praktyków, jak również odbywanie konwersatoriów i spotkań akademików ze studentami/kami i praktykami na terenie współpracującej placówki. Podmiotów tych zazwyczaj może być więcej niż jeden, co daje więcej okazję dla zróżnicowanych doświadczeń i umiejętności praktycznych. Zasady organizacji pracowni zostały wstępnie sformułowane następująco:

- Pracownia ma być rodzajem otwartej mikrospołeczności wzajemnie uczącej się, jej skład będzie zmienny (tutorzy, pracownicy podmiotów edukacyjnych współpracujących z uczelnią, akademicy, studentki/ci, uczniowie, rodzice, pracownicy nadzoru oświaty);

- Szczegółowy regulamin pracowni powstanie w trakcie jej działania i będzie wspólnie negocjowany (niezależnie od wymogów formalnych);

- Powstające w trakcie współpracy strategie dydaktyczne i wzorce metodyczne będą wspólnym dorobkiem wszystkich podmiotów współpracujących z uczelnią.

Odmienne założenia od istniejących już rozwiązań autorskich w zakresie wczesnej edukacji dotyczą podejścia do kształcenia metodycznego, rozwijania profesjonalnej świadomości uczestników oraz pogłębiania ich wiedzy teoretycznej. W prezentowanej koncepcji nie zakłada się określonego modelu rozwoju i strategii dydaktycznej. Realizatorzy projektu pracowni przyjmują zasadę współistnienia zróżnicowanych podejść, które w miarę pogłębiania praktyki i obudowywania jej refleksją mają okazję stać się dojrzałymi strategiami dydaktycznymi tworzonymi przez studiujących i negocjowanymi w praktyce. Zamiarem twórców przyszłej pracowni jest otwarcie metodyczne, a co za tym idzie udzielenie kredytu zaufania przyszłym nauczycielkom/om, ponieważ wydaje się to szansą na przerwanie reprodukcji wzorców opartych na transmisji.

\section{Literatura}

Afeltowicz Ł. (2011), Laboratoria $w$ działaniu. Innowacja technologiczna $w$ świetle antropologii nauki. Warszawa, Oficyna Naukowa.

Bauman T. (2015), Niepraktyczne i łatwe studia pedagogiczne. W: D. Urbaniak-Zając (red.), Akademickie ksztatcenie pedagogów w procesie zmiany. Perspektywy teoretyczne i doświadczenia absolwentów. Kraków, Oficyna Wydawnicza „Impuls”.

Bauman T. (2011), Proces kształcenia w uniwersytecie w perspektywie potrzeb nauczycieli akademickich i oczekiwań studentów. Gdańsk, Wydawnictwo Uniwersytetu Gdańskiego.

Bruner J.S. (2006), Kultura edukacji. Kraków, Univeristas.

Czetwertyńska G. (2008), Laboratorium Edukacyjne OBTA/MISH. W: A. Czetwertyński (red.), Laboratorium Edukacyjne. Warszawa, Laboratorium Edukacyjne MISH Ośrodka Badań nad Tradycją Antyczną.

Dereń A., Tersa J., Sadoń-Osowiecka T. (2010), Nauczycielskie zmagania z podstawa programowa. Ku nowym odczytaniom dokumentów i praktyk szkolnych. Kartuzy, Centrum Inicjatyw Edukacyjnych. 
Filipiak E. (2012), Rozwijanie zdolności uczenia się. Z Wygotskim i Brunerem w tle. Sopot, Gdańskie Wydawnictwo Psychologiczne.

Gołębniak B., Zamorska B. (2014), Nowy profesjonalizm nauczycieli. Podejścia-praktyka-przestrzeń rozwoju. Wrocław, Dolnośląska Szkoła Wyższa.

Gomuła T., Dyrda T. (2006), Standardy przygotowania pedagogicznego kandydatów na nauczycieli, (w:) T. Gomuła, T. Dyrda (red.), Kształcenie kandydatów na nauczycieli. Teoria - praktyka. Kielce, Akademia Świętokrzyska.

Hall E.T. (1978), Ukryty wymiar. Warszawa, Państwowy Instytut Wydawniczy.

Klus-Stańska D., Nowicka M. (2009), Sensy i bezsensy edukacji wczesnoszkolnej. Warszawa, Wydawnictwa Szkolne i Pedagogiczne.

Klus-Stańska D. (2010), Infantylizujacy stereotyp nauczycielki wczesnej edukacji. W poszukiwaniu kontekstu i źródet ukrytego dyskursu „,naszej Pani”. „Kultura i Edukacja”, nr 2(76).

Klus-Stańska D. (red) (2014), Antyedukacja wczesnoszkolna. Kraków, Oficyna Wydawnicza „Impuls”.

Kruk J. (2014), Dezintegracja szkolnego środowiska oraz możliwości jego harmonizowania. W: D. Klus-Stańska (red) (Anty) edukacja wczesnoszkolna, Kraków, Oficyna Wydawnicza „Impuls”.

Kruk J. (2015) Metodyka jako praktyka kulturowa (archetypowa). Ku źródłom zmiany w dydaktyce. „Problemy Wczesnej Edukacji”, nr 1(28).

Kwiatkowska H. (2005), Tożsamość nauczycieli; między anomia a heteronomia. Gdańsk, Gdańskie Wydawnictwo Psychologiczne.

Latour B. (2010), Splatając na nowo to, co społeczne. Wprowadzenie do teorii aktora-sieci. Kraków, Wydawnictwo Universitas.

Łukaszewicz R. (1991), Edukacja dialektyczna i szkoła przyszłości. Wrocław, Zakład Narodowy im. Ossolińskich.

Rutkowiak J., Potulicka E. (2010), Neoliberalne uwikłania edukacji. Kraków, Oficyna Wydawnicza „Impuls”.

Śliwerski B. (2015), Nauczyciele w gorsecie MEN-skich regulacji. W: H. Kwiatkowska (red.), Uczłowieczyć komunikację. Nauczyciel wobec ucznia w przestrzeni szkolnej. Kraków, Oficyna Wydawnicza „Impuls”.

Śliwerski B. (2013), Diagnoza uspolecznienia szkolnictwa publicznego III RP w gorsecie centralizmu. Kraków, Oficyna Wydawnicza „Impuls”.

\section{Akty prawne i publikacje internetowe}

Abriszewski K. (2007), Teoria Aktora-Sieci Bruno Latoura. „Teksty drugie”, 1-2, wyd. Centrum Humanistyki Cyfrowej, http://rcin.org.pl/Content/51075/WA248_67121_P-I-2524_abriszew-teoria.pdf, odczyt 8.08.2018.

Podstawa programowa kształcenia ogólnego z komentarzem, Ministerstwo Edukacji Narodowej, dostęp: 8.08.2018.

Rozporządzenie Ministra Edukacji Narodowej z dnia 24 sierpnia 2017 r. w sprawie praktycznej nauki zawodu (Dz.U. z 2017 r., poz. 1644). 